\title{
Characteristics of the Design of Landscape Lighting of Dongdaeguro in Daegu
}

\author{
Ok-Hee $\mathrm{An}^{*} \cdot \operatorname{In}-\mathrm{Hyo}$ Lee $^{* *}$
}

\begin{abstract}
The research measured 14 spots including four streetlights, five public buildings, and five officetels to obtain data needed for the improvement of townscape, grasping the characteristics of the design of landscape lighting of Dongdaeguro in Daegu Metropolitan city.

The result of the research shows that landscape lighting by outside lightings of buildings had almost no effect and also it was formed with darker landscape lighting due to high buildings that had no effect of outside lighting. In addition, landscape lighting by streetlights have no unity due to different management facilities of the lightstreets.
\end{abstract}

Key Words : Landscape Lighting, Streetlight, Building Lighting

\section{Introduction}

\subsection{Background and purposes of the research}

Landscape lighting illuminates the night and features of buildings. It promotes stability and comfort, and displays an aesthetic mood. Also, the landscape of a city at night provides special sights to the city's visitors as well as to the city's citizens. As our society's active time expands to midnight, the importance of such landscape lighting is

* Main author : Yeungnam University

** Corresponding author: Yeungnam University

Tel : +82-53-810-2860, Fax : +82-53-810-4667

E-mail : aohee@yumail.ac.kr

Date of submit : 2010. 2. 10

First assessment : 2010. 2. 16

Completion of assessment : 2010. 7. 1 emphasized.

More recently, led by Seoul metropolitan-level officer of the city is Establishing or a plan has established Urban Night-Scape Plan[1] .

However, until today, outside lighting of a city mainly consisted of road lights and streetlights for crime prevention. In addition, some landscape lighting was installed for bridges and special objects. The city of Daegu largely lacks landscape lighting during the night for visitors, to form a favorable image of the city.

Our research obtained data useful for the improvement of the city's fine view. We focused on the characteristics of the design of landscape lighting in the vicinity of the Dongdaeguro station, which is a gateway of Daegu. 


\subsection{Scope and method of the research}

The Dondaeguro station, the Fatima hospital, and the Beomeo crossroads were selected to represent the landscape of Daegu for the study. A total of fourteen locations were measured.

The measurement period was from 7 to 12 July, 2008. The locations were measured for one hour after sunset, between the hours of 8:45pm and 12am. The measurement height was the average height of a pedestrian $(150[\mathrm{~cm}])$. The measurement angle was $1 / 3\left[^{\circ}\right]$. The luminance of illuminated planes of the subjects was measured in accordance with the luminance measurement method (KSC7613) and road lighting standard (KSA3701) $<$ Fig1 $>$.
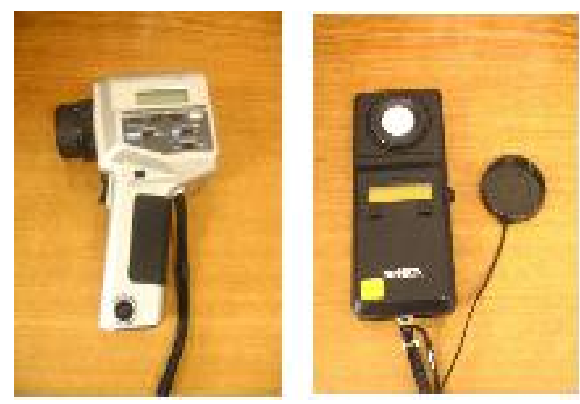

Fig. 1. Measurement machinery

Luminance meters (LS-110) were used on tripods to prevent their vibrations. In order to visually view their luminance, photos were taken in the day and night. Two persons, trained in advance on these methods, performed the measurements.

\section{Dongdaeguro}

\subsection{Local Environment}

The length of Dongdaeguro is about 2,250[m] and its width is about $70[\mathrm{~m}]$. There are six to ten lines.
Dongdaeguro is located in the biggest commercial area of the city of Daegu. The city identified it in 2008 as one of thirteen special landscape management areas.

Dongdaeguro has three crossroads over the road. The characteristics of each crossroad is different. For example, since the section from the Fatima hospital to Dongdaegu station crossroads is a gateway of Daegu, it is closed to Ayangro and it has a lot of traffic.

In the section from Dongdaegu station to the MBC crossroads there are many public buildings and high commercial buildings such as the Dongbu fire station, the Gyeongbuk custom, the chamber of commerce and industry, the Daegu design center, and the culture house for Daegu's juveniles. Since the median strip of the section is planted with many trees, it presents a very unique landscape.

The section from MBC crossroads to the Beomeo crossroads has many commercial facilities and high-rise mixed-use residential buildings that are being constructed, along with the Daegu MBC, the Daegu district court, and the Daegu high court. Since nine mixed-use residential buildings with more than 20 floors are scheduled to be completed around 2010 in this section, it is predicted that a disharmonious skyline will be created due to the mixture of the existing low buildings and the high-rise mixed-use residential buildings $<$ Fig $2>$.

\subsection{Standards of landscape light}

The Commission Internationale de I'Eclairage (CIE) divides the environment into four sections ${ }^{-}$ $\mathrm{E} 1, \mathrm{E} 2, \mathrm{E} 3$, and E4- according to the luminance of an area. The subject area of the research, Dongdaeguro, is a commercial area and belongs in E4. E4 is active during the night time $<$ Table $1>$. 


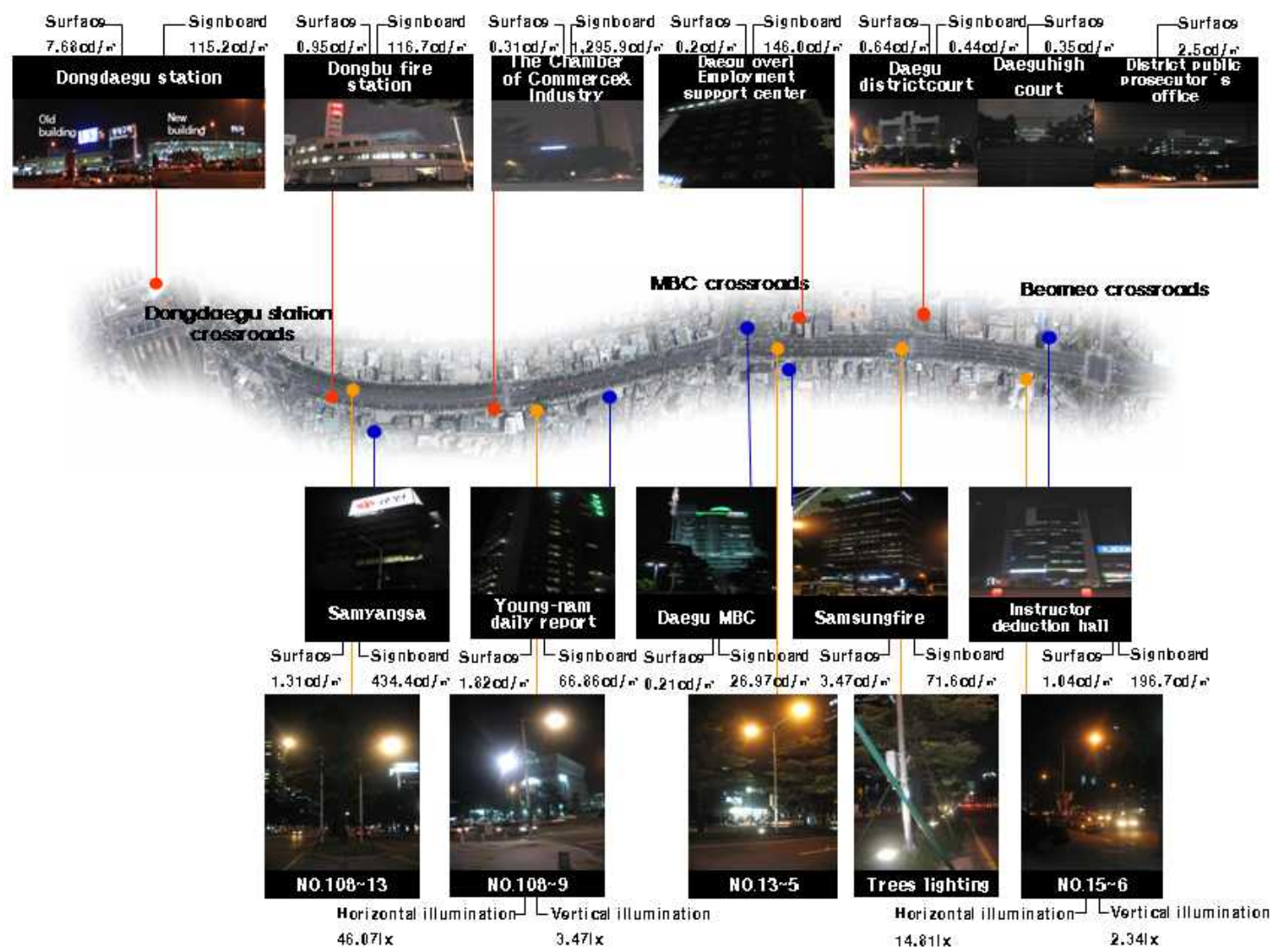

Fig. 2. View of Dongdaeguro

Table 1. ClE Classification and the maximum ostensible luminance of environmental sector

\begin{tabular}{|c|c|c|c|c|}
\hline \multirow[b]{2}{*}{ Area } & \multirow[b]{2}{*}{ Environmental area } & \multirow[b]{2}{*}{ Application } & \multicolumn{2}{|c|}{ Surface type } \\
\hline & & & $\begin{array}{l}\text { Building } \\
\text { Surface }\end{array}$ & $\begin{array}{l}\text { Advertising boad } \\
\text { Surface }\end{array}$ \\
\hline E1 & Area of dark view & National park etc. & 5 & 50 \\
\hline $\mathrm{E} 2$ & $\begin{array}{c}\text { Area of low-end luminance } \\
\text { distribution }\end{array}$ & $\begin{array}{l}\text { The suburbs and } \\
\text { suburban-style housing }\end{array}$ & 5 & 400 \\
\hline E3 & $\begin{array}{c}\text { Area of luminance distribution } \\
\text { of intermediate degree }\end{array}$ & Town residencial area & 10 & 800 \\
\hline $\mathrm{E} 4$ & $\begin{array}{c}\text { Area of high luminance } \\
\text { dispersion }\end{array}$ & $\begin{array}{l}\text { The area where the } \\
\text { nighttime activity is active }\end{array}$ & 25 & 1000 \\
\hline
\end{tabular}

Also, Korean industrial standards(KS) divide roads into four sections according to their traffic and localities, and suggests standards of horizontal illumination and vertical illumination as follows $<$ Table 2>. 
Table 2. KS Standard(KS A 3701-1991)- standard of illumination of road about pedestrian

\begin{tabular}{|c|c|c|c|}
\hline \multirow{2}{*}{$\begin{array}{l}\text { Pedestrian } \\
\text { traffic at } \\
\text { nighttime }\end{array}$} & \multirow[b]{2}{*}{ Area } & \multicolumn{2}{|c|}{ Illumination $([\mathrm{lx}])$} \\
\hline & & $\begin{array}{l}\text { Horizontal } \\
\text { illumination }\end{array}$ & $\begin{array}{c}\text { Vertical } \\
\text { illumination }\end{array}$ \\
\hline \multirow{2}{*}{$\begin{array}{l}\text { Road where } \\
\text { there is much } \\
\text { traffic }\end{array}$} & $\begin{array}{c}\text { Residencial } \\
\text { area }\end{array}$ & 5 & 1 \\
\hline & $\begin{array}{c}\text { commercial } \\
\text { area }\end{array}$ & 20 & 4 \\
\hline \multirow{2}{*}{$\begin{array}{c}\text { Road where } \\
\text { there is rarely } \\
\text { traffic }\end{array}$} & $\begin{array}{c}\text { Residencial } \\
\text { area }\end{array}$ & 3 & 0.5 \\
\hline & $\begin{array}{c}\text { commercial } \\
\text { area }\end{array}$ & 10 & 2 \\
\hline
\end{tabular}

\section{Characteristics of landscape lighting in Dongdaeguro}

\subsection{Characteristics of landscape lighting according to buildings}

Since buildings near Dongdaeguro are more public than commercial (department stores, selling agencies, etc.), there are not many incidences of landscape lighting among buildings.

Signboards of buildings are usually installed on the outside walls or roofs of buildings. Only one building (the Daegu building of Samyang Corporation) has a relatively wide signboard compared with the size of the building.

Sodium lamps, LED, metal halide lamps, neon, fluorescent lamps, cold cathode, and other sources are used for lighting outside buildings. Among the sources, LED is used the most. These light sources are usually used for sign boards and outside sign lamps $<$ Table $3>$.

In July the luminance of buildings was measured. The skylight was $0.03 \sim 0.38\left[\mathrm{~cd} / \mathrm{m}^{2}\right]$. The luminance of building surfaces was $0.2 \sim 12.81\left[\mathrm{~cd} / \mathrm{m}^{2}\right]$. They did not meet the standards of CIE. They were too low.

The luminance of inside lightings coming through windows was $4.06 \sim 2260\left[\mathrm{~cd} / \mathrm{m}^{2}\right]$. Except for the new Dongdaegu station building, of which the luminance of inside lightings was $2260\left[\mathrm{~cd} / \mathrm{m}^{2}\right]$, we believe the luminance of inside lightings of other buildings hardly influenced the landscape lighting. Since the outside walls of the new Dongdaegu station were built with windows, its inside lighting radiates outside through the windows and functions as an outside lighting. It shows a very high level of luminance $<$ Table $4>$.

Table 3. Lighting present condition by Building

\begin{tabular}{|c|c|c|c|c|c|}
\hline & \multirow[b]{2}{*}{ Pictures } & \multicolumn{3}{|c|}{ Lighting present condition } \\
\hline & & & $\begin{array}{c}\text { Present } \\
\text { part }\end{array}$ & $\begin{array}{l}\text { Lighting } \\
\text { fixtures }\end{array}$ & $\begin{array}{l}\text { Lighting } \\
\text { method }\end{array}$ \\
\hline \multirow{2}{*}{$\begin{array}{c}\text { Public } \\
\text { buildings }\end{array}$} & $\begin{array}{l}\text { Dongdaegu } \\
\text { station }\end{array}$ & Old & $\begin{array}{c}\text { Outer wall } \\
\text { Letters } \\
\text { signboard }\end{array}$ & $\begin{array}{c}\text { Sodium-vapor } \\
\text { lamp } \\
\text { LED } \\
\text { Metal Halide Lamp }\end{array}$ & $\begin{array}{l}\text { Down lighting } \\
\text { Uplighting }\end{array}$ \\
\hline & $\begin{array}{c}\text { Dongbu } \\
\text { fire station }\end{array}$ & 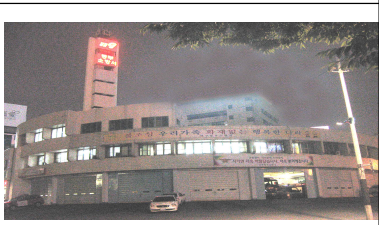 & $\begin{array}{l}\text { Letters } \\
\text { signboard }\end{array}$ & Neon sign & Luminescence \\
\hline
\end{tabular}


Ok-Hee An • In-Hyo Lee

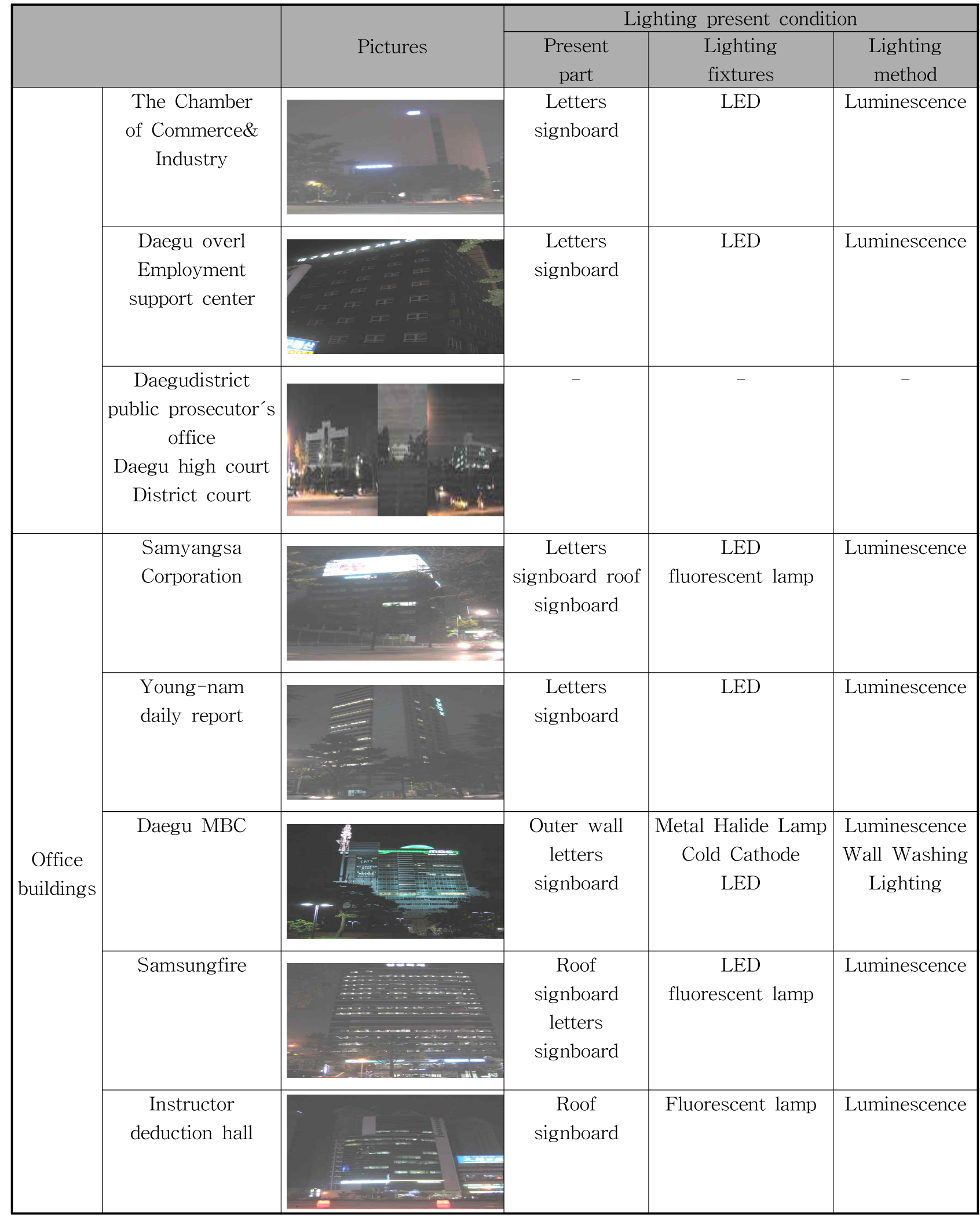


Table 4. Luminance distribution by Building

\begin{tabular}{|c|c|c|c|c|c|c|c|c|}
\hline & \multirow[b]{2}{*}{ Pictures } & \multicolumn{5}{|c|}{ luminance distribution $\left(\left[\mathrm{cd} / \mathrm{m}^{2}\right]\right)$} \\
\hline & & & & \multirow{2}{*}{ 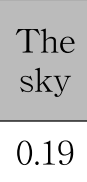 } & \multirow{2}{*}{$\begin{array}{c}\begin{array}{c}\text { Building } \\
\text { surface }\end{array} \\
7.68\end{array}$} & \multirow{2}{*}{\begin{tabular}{|c}
$\begin{array}{c}\text { Surface of } \\
\text { advertising } \\
\text { board }\end{array}$ \\
58.03
\end{tabular}} & \multirow{2}{*}{$\begin{array}{l}\text { The inner light } \\
\text { which leads } \\
\text { the window } \\
4.06\end{array}$} & \multirow{2}{*}{$\begin{array}{l}\text { Sign- } \\
\text { board }\end{array}$} \\
\hline \multirow{8}{*}{$\begin{array}{c}\text { public } \\
\text { buildings }\end{array}$} & \multirow{2}{*}{$\begin{array}{l}\text { Dong } \\
\text { daegu } \\
\text { station }\end{array}$} & Old building & \multirow{2}{*}{$\begin{array}{lll}\text { Old } & \text { New } \\
\text { building } & \text { building }\end{array}$} & & & & & \\
\hline & & New building & & 0.15 & 12.81 & - & 2260 & 93.74 \\
\hline & \multicolumn{2}{|c|}{ Dongbu fire station } & 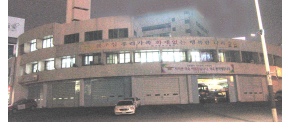 & 0.33 & 0.95 & - & 13.31 & 116.7 \\
\hline & \multicolumn{2}{|c|}{$\begin{array}{l}\text { The Chamber } \\
\text { of Commerce\& } \\
\text { Industry }\end{array}$} & & 0.08 & 0.31 & - & 3.31 & 1295.9 \\
\hline & \multicolumn{2}{|c|}{$\begin{array}{l}\text { Daegu overl } \\
\text { Employment } \\
\text { support center }\end{array}$} & & 0.04 & 0.2 & - & - & 146 \\
\hline & \multicolumn{2}{|c|}{$\begin{array}{l}\text { Daegu district public } \\
\text { prosecutor's office }\end{array}$} & & 0.03 & 0.64 & - & - & 0.44 \\
\hline & \multicolumn{2}{|c|}{ Daegu high court } & In. & 0.05 & 0.35 & - & - & - \\
\hline & \multicolumn{2}{|c|}{ Daegu district court } & Xativis & 0.06 & 2.5 & - & 7.7 & - \\
\hline \multirow{5}{*}{$\begin{array}{l}\text { Office } \\
\text { buildings }\end{array}$} & \multicolumn{2}{|c|}{$\begin{array}{l}\text { Samyangsa } \\
\text { Corporation }\end{array}$} & & 0.2 & 1.31 & 202.1 & 11.84 & 434.4 \\
\hline & \multicolumn{2}{|c|}{$\begin{array}{l}\text { Young-nam } \\
\text { daily report }\end{array}$} & & 0.08 & 1.82 & - & 5.91 & 66.86 \\
\hline & \multicolumn{2}{|c|}{ Daegu MBC } & & 0.04 & 0.21 & - & 16.2 & 26.97 \\
\hline & \multicolumn{2}{|c|}{ Samsung fire } & $\ldots=\ldots \ldots$ & 0.38 & 3.47 & - & 13.2 & 71.6 \\
\hline & \multicolumn{2}{|c|}{$\begin{array}{c}\text { Instructor } \\
\text { deduction hall }\end{array}$} & 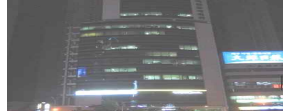 & 0.05 & 1.04 & - & 4.7 & 196.7 \\
\hline
\end{tabular}




\subsection{Characteristics of lighting environment of streetlights}

Because Dongdaeguro is a wide road, a median strip and streetlights in sidewalks were installed. The section from Fatima hospital to the MBC crossroads is managed by Donggu, and the section from MBC crossroads to Beomeo crossroads is managed by Suseonggu. There is no difference in the kinds of road surface, the widths of road, the methods to arrange lamp poles, and the heights of lamp poles, but there are differences of $25-40[\mathrm{~m}]$ exist in the distances of lamp poles. It is believed the reason that the distances of lamp poles are different is because of road conditions that cannot apply the same distance for lamp poles.

The reason the lamps and light sources are different is believed to be because of the different management facilities. The section managed by Donggu has metal halide lamps with a cutoff type, and the section managed by Suseonggu has high pressure sodium lamps with a semi cutoff type.
The horizontal illumination of Dongdaegu station crossroads to $\mathrm{MBC}$ crossroads was $46.07[\mathrm{~lx}]$ and the vertical illumination was $3.47[\mathrm{~lx}]$. The horizontal illumination met the standard but the vertical illumination did not reach the standard of $4[\mathrm{~lx}]$.

The horizontal illumination of $\mathrm{MBC}$ crossroads to Beomeo crossroads was $14.61[\mathrm{x}]$ and the vertical crossroads of it was 2.34[1x]. Both did not reach the standards because Daegu city had an every-second-streetlight-turnoff-system to prepare for the rising oil prices from 11 July. The number of streetlights turned off due to the system was 20,700, and Daegu city predicted that about 1.9 billion won would be saved for one year. However, since the every-second-streetlight-turnoff-system drops the visibility of a driver at night, the risk of car accidents increases.

In Dongdaeguro, the median strip is planted with trees and the road is wide, and there is almost no lighting effect of the opposite streetlights. Consideriation of this road environment, as an energy saving plan should be made<Table 5>.

Table 5. Condition of streetlights(2008)

\begin{tabular}{|c|c|c|c|c|c|}
\hline \multicolumn{2}{|c|}{ Avenue } & \multicolumn{2}{|c|}{$\begin{array}{l}\text { The section from Dongdaegu station to } \\
\text { MBC crossroads }\end{array}$} & \multicolumn{2}{|c|}{$\begin{array}{c}\text { The section from } \\
\text { MBC crossroads to Beomeo crossroads }\end{array}$} \\
\hline \multicolumn{6}{|c|}{ Pictures } \\
\hline \multicolumn{2}{|c|}{ Administrative district } & \multicolumn{2}{|c|}{ Donggu } & \multicolumn{2}{|c|}{ Suseonggu } \\
\hline \multicolumn{2}{|c|}{ Road surface type } & \multicolumn{4}{|c|}{ Concrete } \\
\hline \multicolumn{2}{|c|}{ Road length([m]) } & \multicolumn{2}{|c|}{1,000} & \multicolumn{2}{|c|}{760} \\
\hline \multicolumn{2}{|c|}{ Road width $([\mathrm{m}])$} & \multicolumn{2}{|c|}{60} & \multicolumn{2}{|c|}{60} \\
\hline \multicolumn{2}{|c|}{ Arrangement method of lamp poles } & \multicolumn{2}{|c|}{ Zigzag } & \multicolumn{2}{|c|}{ Zigzag } \\
\hline \multicolumn{2}{|c|}{ Heights of lamp poles $([\mathrm{m}])$} & \multicolumn{2}{|c|}{10} & \multicolumn{2}{|c|}{10} \\
\hline \multicolumn{2}{|c|}{ Distances of lamp poles ([m]) } & $25 \sim 40$ & $32 \sim 33$ & $33 \sim 40$ & $34 \sim 38$ \\
\hline \multicolumn{2}{|c|}{ Lighting form } & \multicolumn{2}{|c|}{ Cut off } & \multicolumn{2}{|c|}{ Semi cut off } \\
\hline \multicolumn{2}{|c|}{ Source of illumination } & Metal Halide Lamp & Metal Halide Lamp & High tension sodium-vapor lamp & High tension sodium-vapor lamp \\
\hline \multirow{2}{*}{ Illumination ([lx]) } & Horizontal illumination & \multicolumn{2}{|c|}{46.07} & \multicolumn{2}{|c|}{14.61} \\
\hline & \begin{tabular}{|l|} 
Vertical illumination \\
\end{tabular} & \multicolumn{2}{|c|}{3.47} & \multicolumn{2}{|c|}{2.34} \\
\hline
\end{tabular}




\section{Results}

Our study measured fourteen locations including four streetlights, five public buildings, and five officetels near Dongdaeguro. The data we compiled can be useful for improving the city landscape, and the design of the landscape in Dongdaeguro of Daegu metropolitan city.

The results of the study suggest that landscape lighting by outside lighting has almost has no effect, and also darker landscape lighting is formed by high buildings which have no effect on outside lighting. In addition, landscape lightings by streetlights have no unity due to different management facilities.

Therefore, a total lighting design that makes architectures, lightings, and surrounding environments consistant and harmonized is needed. The design must take into account the image of the city, Daegu. It must also display the characteristics of buildings, secure stability and comfort and include aesthetical landscape lighting.

\section{References}

[1] Jeong-Ah, Kim, "A Comparative Study on the Urban Lighting Planning Systems of Paris and Lyon in France", Architectural Institute of Korea, Autumn conference, vol. 5, no. 2, pp73 81, 2005.

[2] Whayoung Shin, et al., "Characteristics of lighting environment within the field of vision viewed from the path of Cheongye Stream," Architectural Institute of Korea, Autumn conference, vol. 5, no. 2, pp73 81, 2005.

[3] Yugun Jeong, "Investigation on the lighting environment of subway stations in Seoul," Korean Institute of Illuminating and electrical installation engineers, vol.18, no.3, pp40 47, 2004.
[4] Kwangseop Jeon, et al., "Requisites and standards of road lightings," Korean Institute of Illuminating and electrical installation engineers, vol.12, no.1, pp3 12, 1998.

[5] Hyeongkwon Kim, et al., "Investigation on road lighting through the measurement of illumination/luminance," Korean Institute of Illuminating and electrical installation engineers, vol.22,no.1,2008.

[6] Seongryul Park, et al.,"Analysis on the characteristics of the surface luminance of the building surfaces of shopping malls at night," Korea institute of ecological architecture and environment, Autumn conference, vol.7,no.1,pp39 42, 2007.

[7] Juyoung Shin, et al., "Analysis on the characteristics of lighting environment according to the types of commercial streets," Korea institute of ecological architecture and environment, Autumn conference, vol.7,no.1,pp21 24,2007.

\section{This research was supported by the Yeungnam} University research grants in 2010

\section{Biography}

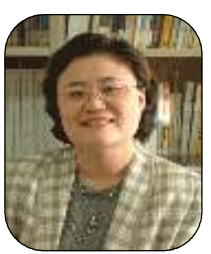

\section{Ok-Hee An}

An, Ok-Hee was born in 1961. In 1990, She awarded the degree of doctor of Human Ecology in Nara Women's University in Japan. Now she serves as a professor of department of Family \& Housing studies in Yeungnam University.

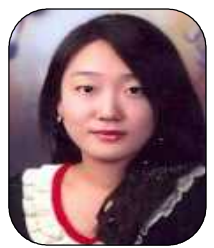

\section{In-hyo Lee}

Lee, In-Hee was born in 1981. In 2008, She awarded the Master's degree of Housing study in Yeungnam University. Now she is doctor's course of department of Family \& Housing studies in Yeungnam University. 